\title{
Energy Efficient Biomass Cookstoves: Performance Evaluation, Quality Assurance and Certification
}

\author{
Izuchukwu Francis Okafor \\ National Stove Eligibility Laboratory, National Center for Energy Research and Development, University of Nigeria, Nsukka, Nigeria
}

\section{Email address:}

izuchukwu.okafor@unn.edu.ng

\section{To cite this article:}

Izuchukwu Francis Okafor. Energy Efficient Biomass Cookstoves: Performance Evaluation, Quality Assurance and Certification. Science Journal of Energy Engineering. Vol. 7, No. 4, 2019, pp. 54-62. doi: 10.11648/j.sjee.20190704.11

Received: January 28, 2019; Accepted: March 19, 2019; Published: October 25, 2019

\begin{abstract}
This study investigated the thermal and emissions performance characteristics of biomass cookstoves developed by the National Center for Energy Research and Development (NCERD) as well as other biomass cookstoves received by the Centre from stove designers and manufactures to ensure conformity with stipulated standard. The Center has acquired a Laboratory emissions monitoring system (LEMS) domicile at its National Stove Eligibility Laboratory (NSEL) for comprehensive biomass cookstoves performance evaluations. Water boiling test (WBT) and food cooking (rice and beans) tests were conducted with at the NSEL with LEMS for firewood and charcoal cookstoves to determine their thermal and emissions performance characteristics. Out of 15 sample charcoal stoves tested, $62 \%$ satisfied the minimum standard of tier 2, while $51 \%$ of 10 sample of firewood stoves tested satisfied the minimum standard of tier 2. The star rating of a biomass cookstove is determined from the thermal efficiency tier value of the stove. The available cookstoves in the local markets in Nigeria do not display any star rating. It was also found that nearly all the biomass cookstoves available in the local markets in Nigeria have not been tested and few tested ones at NSEL, NCERD were inconclusive. This could be attributed to non-enforcement of the standard and possibly lack of fund and incentives to enable the stove producers to undertake for full testing of the required sample test number of the stoves by Standard to attain full certifications.
\end{abstract}

Keywords: Biomass Cookstoves, Performance Standard, Energy Efficiency, Emissions and Thermal Performance

\section{Introduction}

In Nigeria, about $67 \%$ of the country's population depends on fuel wood for their daily cooking. Cooking with fuel wood in Nigeria is mostly through the poor energy efficient traditional open fire method [1]. Initial efforts to spread the use of energy efficient cook stoves in Nigeria were poorly designed and thus yielded limited results [2]. Presently, different types of both wood and charcoal cookstoves with uncertified quality and safety issues are now available in the markets in Nigeria. The National Mirror Committee on Clean Cooking Solution in Nigeria under the leadership of SON of developed a Standard for Biomass cookstoves in Nigeria to ensure quality compliance. Inefficient and poor quality cookstoves waste fuel wood, create health problems and emissions into the environment [3, 4]. It has been estimated that about 1.6 million people, mainly women and children, die every year as a result of the smoke from wood stoves [5]. In a study carried out by [6] in Delta State of Nigeria with a sample size of 500 rural dwellers noted that $14.60 \%$ suffered red eyes, $71.60 \%$ cough complications, and $6.80 \%$ suffered sneezing due to exposures to smoke in their cooking environment.

To address the issues associated with the use of efficient performance of biomass cookstoves, it is imperative that stoves manufacturers mandated by the Standard Organization of Nigeria (SON) to test their stoves in a standard Laboratory for conformity and quality assurance. The lack of standard Laboratory in the country has hampered quality assurance and performance evaluation standard of the existing biomass cookstoves in the country. The study by Unchukwu et al [7] on benchmarking of energy consumption of common domestic cookstoves in Nigeria only considered the thermal performance characteristics determined from WBT, while the emissions performance was neglected. Also, the study by Ayo [8] on design, construction and testing of an improved wood stove was limited to thermal performance and the emissions characteristics were not investigated. Presently, studies that 
could provide detailed information on thermal and emissions performance standard of the biomass cookstoves available in the country are lacking in the literature. However, the National Stove Eligibility Laboratory of the National Centre for Energy Research and Development, University of Nigeria Nsukka (UNN) has acquired the state-of-the-art technology for thermal performance analysis and indoor emissions monitoring system, developed by Aprovecho Research Center, Oregon USA, for comprehensive performance evaluations of biomass cookstoves [9]. Since the inception of the Lab, the Centre has acquired expertise in design, manufacture and testing of improved biomass cookstoves (charcoal, wood and briquettes fired). The Centre has conducted comprehensive performance evaluation of biomass cookstoves based on water boiling tests and field testing and verifications/certifications of a number of biomass cookstoves and also works in partnership with Standard Organistion of Nigeria (SON) in manpower training and in developing the standard on biomass clean cookstoves.

\section{Biomass Cookstoves Performance Evaluation}

A number of standard methods have developed for evaluating the performance of biomass cook stoves. Such methods are the constant heat output, constant temperature rise, constant time and water boiling test $[10,11]$. But water boiling test is mostly used because it is short and provides a simple simulation of standard cooking procedures. It measures the quantity of fuel consumed and time required for the simulated cooking and usually employed in investigating the performance of cook stoves under different operating conditions [12]. It also provides a quick method of comparing the performance of cook stoves. This method has been adopted in evaluating and comparing the performance of the biomass cookstoves developed at the National Stove Eligibility Laboratory (NSEL), NCERD, UNN and other biomass stoves received from designers as well as manufactures for performance evaluations and their certifications. The performance evaluation of the biomass cookstoves conducted with the LEMS at NSEL covers both thermal and emission performance characteristics of the biomass cookstoves.

\subsection{Emissions Performance Evaluation of Biomass Cookstoves}

The emissions performance characteristics of a biomass cookstove can be determined through water boiling test (WBT) using a Laboratory Emissions Monitoring System. The WBT protocol is described in version 4.2.3 [13, 14]. The test consists of three phases: high-power (cold start) phase, high power (hot start) phase, and low power (simmer) phase. These test phases are very important indicators in evaluating the performance ability of cookstoves to conserve fuel and emissions performance. The apparatus required for the test include: (i) Cooking pots, (ii) thermocouple for measuring the ambient and temperature of the water being heated, (iii) A digital balance for measuring the weight of the fuelwood, charcoal, water and cooking pot. (iv) Laboratory emissions monitoring system (LEMS) developed by Aprovecho Research Center [9] is used for the WBT. It quantifies the emissions from cookstoves by collecting, measuring and analyzing the emissions: $\mathrm{CO}_{2}, \mathrm{CO}$ and particulate matter (PM) emitted from the stove.

Figure 1 shows the LEMS at the National Stove Eligibility Laboratory, NCERD, UNN, with a nozzle type biomass energy efficient cookstove developed by the Centre, mounted inside the metal hood of the LEMS during water boiling tests. The LEMS consists of carbon monoxide (CO) sensor, which is an electrochemical cell with two electrodes.

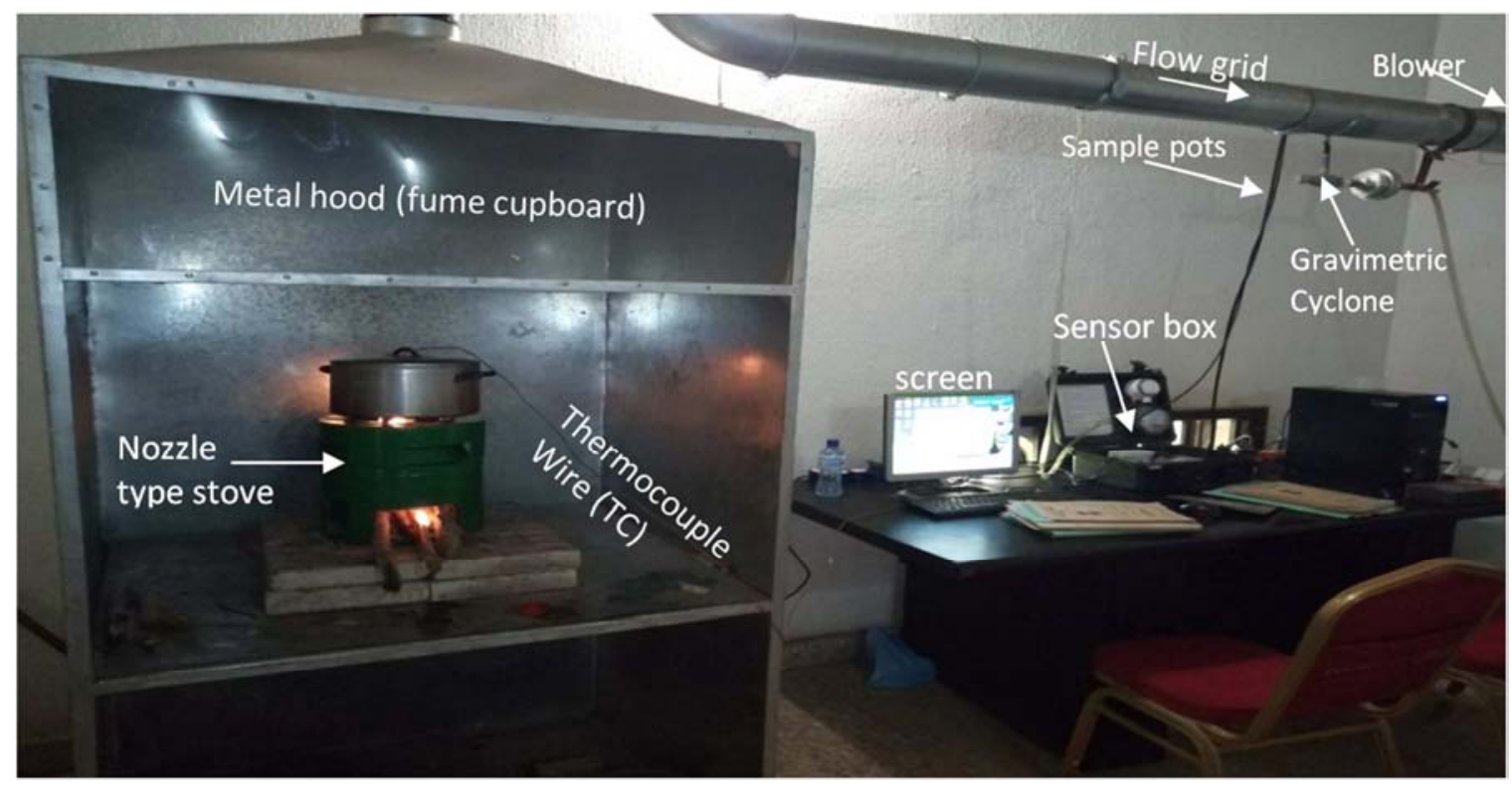

Figure 1. Laboratory emissions monitoring system with the nozzle type energy efficient cookstove mounted inside the metal hood. 
The conductivity between the two electrodes gives the proportional concentration of the $\mathrm{CO}$ produced by the stove under testing. The carbon dioxide $\left(\mathrm{CO}_{2}\right)$ sensor uses nondispersive infrared to measure $\mathrm{CO}_{2}$ concentration and outputs voltage [9]. The LEMS has two particulate matter (PM) sensors - the gravimetric system and light scattering photometer. The gravimetric system gives a direct measurement of total PM using filter-based sampling. The light scattering photometer has both a laser and a light receiver. When smoke enters the sensing chamber, particles of smoke scatter the laser light into the receiver and more light reaching the receiver indicates more smoke in the chamber. The flow grid is an amplified pitot tube that provides a low pressure drop through the system and a strong differential pressure signal, averaged across the entire duct cross-section. The exhaust gas velocity, volume, and mass flow rate within the duct, are calculated based on pressure drop recorded using the Magnesense pressure transducer. The thermocouple (TC) temperature sensor is used to record the water temperature of the pot. The thermocouple temperature output is linear and the thermocouple probe provided with the LEMS is rated for temperatures up to $250^{\circ} \mathrm{C}$ [9].

\subsection{Thermal Performance Evaluation of Biomass Type Cookstove}

The thermal performance characteristics of any biomass type cookstove can be determined from the WBT with the Laboratory Emissions Monitoring System based on the parameters described in Equations (1) to (8).

(i) Burning rate of the stove
The burning rate $\mathrm{R}(\mathrm{g} / \mathrm{min})$ which measures how economically the stove burns the fuel wood in its combustion chamber is determined using Equation (1) [12]:

$$
R=\left[\frac{100\left(W_{i}-W_{f}\right)}{(100+M)}-\frac{M_{c} H_{c}}{H_{w}}\right] \frac{1}{t}
$$

$W_{i}$ is the initial weight of fuelwood at start of test $(\mathrm{g}), W_{f}$ is the final weight of fuelwood at end of test $(\mathrm{g}), M$ is the moisture content of fuelwood $(\%), \mathrm{H}_{\mathrm{c}}$ is the Calorific value of charcoal $(28.8 \mathrm{MJ} / \mathrm{kg}), \mathrm{M}_{\mathrm{c}}$ is the weight of charcoal $(\mathrm{g}), \mathrm{H}_{\mathrm{w}}$ is the Calorific value of fuel wood $(15.5 \mathrm{MJ} / \mathrm{kg})$ and $\mathrm{t}$ is the total time taken for boiling the water.

(ii) Thermal efficiency of the stove

The thermal efficiency measures how the heat generated by the stove is utilized in boiling the water or in cooking the food. The thermal efficiency $\left(\eta_{t h}\right)$ of the stove can be determined using the Equation (2) [15].

$$
\eta_{t h}=\eta_{h} \times \eta_{c}
$$

It is also related to the percentage heat utilized ( $P H U$ ) by the stove, which is given as:

$$
\eta_{t h}=\text { Burning Rate x } P H U
$$

The percentage heat utilized (PHU) is determined by Equation (4).

$$
\mathrm{PHU}=\frac{\text { Heat energy reaching water in the pot (output) }}{\text { Heat energy produced by the burning by the burning fuel (Input) }} \times 100 \%
$$

$$
\text { Heat Energy Output }=M_{w} C_{w}\left(T_{b}-T_{i}\right)+M_{e} L
$$

$\mathrm{M}_{\mathrm{w}}=$ Initial amount of water in the Pot $(\mathrm{kg})$

$\mathrm{C}_{\mathrm{w}}=$ Specific heat of water $\left(\mathrm{kJ} / \mathrm{kg} /{ }^{\circ} \mathrm{C}\right)$

$\mathrm{T}_{\mathrm{b}}=$ Boiling temperature of water $\left({ }^{\circ} \mathrm{C}\right)$

$\mathrm{Ti}=$ Initial temperature of water in the Pot $\left({ }^{\circ} \mathrm{C}\right)$

$\mathrm{M}_{\mathrm{e}}=$ Amount of water evaporated $(\mathrm{kg})$

$\mathrm{L}=$ Latent heat of water evaporation at atmospheric pressure and $100(\mathrm{~kJ} / \mathrm{kg})$

$$
\text { Heat Energy Input }=\mathrm{M}_{\mathrm{f}} \times \mathrm{E}_{\mathrm{f}}
$$

$\mathrm{M}_{\mathrm{f}}=$ amount of fuel burnt $(\mathrm{kg})$,

$\mathrm{E}_{\mathrm{f}}=$ calorific value of fuel used $(\mathrm{kJ} / \mathrm{kg})$

(iii) Specific fuel consumption ( $S F C$ )

The specific fuel consumption is expressed in Equation (7).

$$
S F C=\frac{\left\lfloor W_{f}(1-M)-1.5 M_{C}\right\rfloor}{M_{w}}
$$

(iv) Power consumption for boiling or simmering:

This measures the wood energy consumed by the stove per unit time. It indicates the average power output of the stove (in Watts) during the high-power test. The power consumed
$(P C$ ) for boiling water is expressed in Equation (8).

$$
P C=\frac{\left\lfloor W_{f}(1-X)-1.5 M_{C}\right\rfloor \times H_{w}}{60 t}
$$

\section{Biomass Cookstoves Testing at National Stove Eligibility Laboratory, NCERD}

The emissions and thermal performance characteristics of biomass cookstoves have been conducted at the National Stove Eligibility Laboratory, NCERD, via water boiling test and food cooking (beans and rice) tests. The summary of tests results for both firewood and charcoal stoves are presented in this section.

\subsection{WBT Results for Firewood and Charcoal Cookstoves}

Figure 2 indicates the real-time PM, pot temperature, and relative humidity profiles and Figure 3 indicates the real-time $\mathrm{CO}_{2}$ and $\mathrm{CO}$ emissions profiles during the cold start (highpower), hot start (high-power) and simmer (low-power) 
phases of the WBT respectively, plotted from the LEMS software code [9].

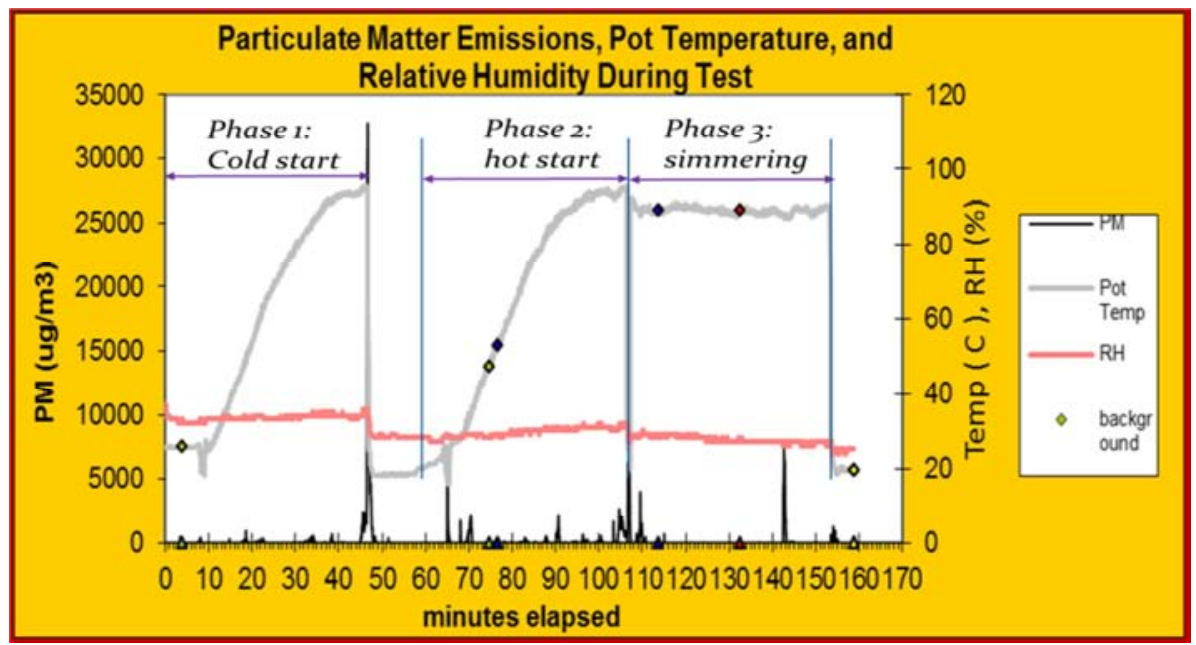

Figure 2. Particulate matter (PM), pot temperature, and relative humidity during WBT.

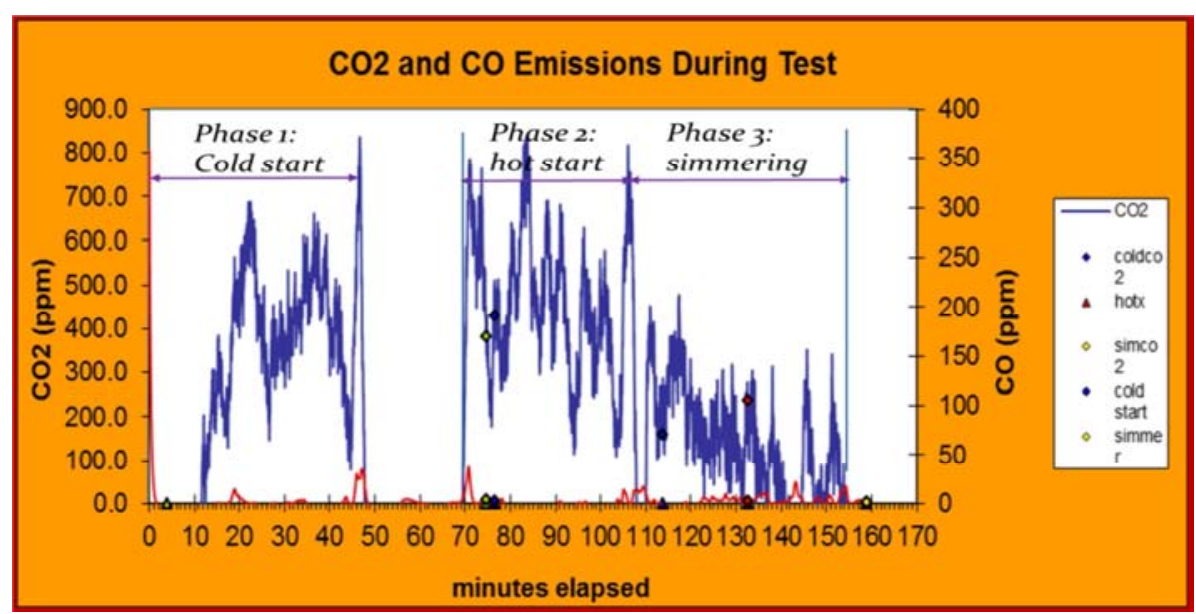

Figure 3. $\mathrm{CO}_{2}$ and $\mathrm{CO}$ emissions during $\mathrm{WBT}$.

Table 1 compares the performance of the nozzle type cookstove and the minimum performance standard (Tier 2) for biomass cookstoves established by Standard Organization of Nigeria (SON) [16]. It can be observed in Table 1 that the thermal and emission performance values of the stove are in line with the minimum performance standard of Tier 2 acceptable by IWA [16, 17].

Table 1. International workshop agreement (IWA) performance metrics.

\begin{tabular}{llll}
\hline IWA Performance Metrics & Units & Nozzle type cookstove performance & Minimum standard (Tier 2)* \\
\hline High Power Thermal Efficiency & $\%$ & 26.4 & $>25.0$ \\
Low Power Specific Consumption Rate & $\mathrm{MJ} / \mathrm{min} / \mathrm{L}$ & 0.036 & $<0.039$ \\
High Power CO & $\mathrm{g} / \mathrm{MJd}$ & 10.97 & $<11$ \\
Low Power CO & $\mathrm{g} / \mathrm{min} / \mathrm{L}$ & 0.18 & $<0.13$ \\
High Power PM & $\mathrm{mg} / \mathrm{MJd}$ & 352.0 & $<386$ \\
Low Power PM & $\mathrm{mg} / \mathrm{min} / \mathrm{L}$ & 3.76 & $<4$ \\
Indoor Emissions CO & $\mathrm{g} / \mathrm{min}$ & 0.61 & $<0.62$ \\
Indoor Emissions PM & $\mathrm{mg} / \mathrm{min}$ & 15.9 & $<17$ \\
\hline
\end{tabular}

*Source: Nigerian Industrial Standard, FDNIS 1000: 2017 [16]

Tables 2 and 3 show summaries of the performance characteristics of some of the firewood and charcoal cookstoves that have been tested at the National Stove eligibility laboratory, NCERD, UNN. Out of 15 sample charcoal stoves tested, $62 \%$ satisfied the minimum standard of tier 2, while $51 \%$ of 10 sample of firewood stoves tested satisfied the minimum standard of tier 2. 
Table 2. WBT results for firewood cookstoves.

\begin{tabular}{|c|c|c|c|c|}
\hline IWA Performance metrics & Units & Performance range & & Minimum standard (*Tiers 2) \\
\hline High power thermal efficiency & $\%$ & $18.0-37.40$ & $\geq$ & 0.25 \\
\hline Low power specific consumption & $\mathrm{MJ} / \mathrm{min} / \mathrm{L}$ & $0.041-0.052$ & $\leq$ & 0.039 \\
\hline High power $\mathrm{CO}$ & g/MJd & $0.13-9.33$ & $\leq$ & 11 \\
\hline Low power $\mathrm{CO}$ & $\mathrm{g} / \mathrm{min} / \mathrm{L}$ & $0.04-0.12$ & $\leq$ & 0.13 \\
\hline High power PM & $\mathrm{mg} / \mathrm{MJd}$ & $30.6-311.6$ & $\leq$ & 386 \\
\hline Low power PM & $\mathrm{mg} / \mathrm{min} / \mathrm{L}$ & $0.18-3.91$ & $\leq$ & 4 \\
\hline Indoor Emissions $\mathrm{CO}$ & $\mathrm{g} / \mathrm{min}$ & $0.03-0.57$ & $\leq$ & 0.62 \\
\hline Indoor Emissions PM & $\mathrm{mg} / \mathrm{min}$ & $2.30-18.5$ & $\leq$ & 17 \\
\hline
\end{tabular}

*Source: Nigerian Industrial Standard, FDNIS 1000: 2017 [16]

Table 3. WBT results for charcoal cookstoves.

\begin{tabular}{llll}
\hline IWA Performance metrics & Units & Performance range & Minimum standard (*Tiers 2) \\
\hline High power thermal efficiency & \% & $20.0-41.40$ & $\geq$ \\
Low power specific consumption & $\mathrm{MJ} / \mathrm{min} / \mathrm{L}$ & $0.003-0.045$ & 0.25 \\
High power CO & $\mathrm{g} / \mathrm{MJd}$ & $2.14-9.32$ & 0.039 \\
Low power CO & $\mathrm{g} / \mathrm{min} / \mathrm{L}$ & $0.02-0.09$ & 11 \\
High power PM & $\mathrm{mg} / \mathrm{MJd}$ & $13.8-242.7$ & $\leq$ \\
Low power PM & $\mathrm{mg} / \mathrm{min} / \mathrm{L}$ & $0.012-2.98$ & $\leq .13$ \\
Indoor Emissions CO & $\mathrm{g} / \mathrm{min}$ & $0.10-0.52$ & 386 \\
Indoor Emissions PM & $\mathrm{mg} / \mathrm{min}$ & $1.30-16.80$ & $\leq$ \\
\hline
\end{tabular}

*Source: Nigerian Industrial Standard, FDNIS 1000: 2017 [16]

\subsection{Food Cooking (Beans and Rice) Tests Results for Charcoal Cookstoves}

The rice and beans cooking tests results with a charcoal cookstove designed and produced in NCERD for a family of four to eight people are presented in table 4. Figure 1 shows the experimental test rig of the laboratory emissions monitoring system used for the hexagonal type charcoal cookstove for the rice and beans cooking tests. Figure 4 and 5 indicate the real-time PM, pot temperature, and relative humidity profiles and Figure 6 and 7 indicate the real-time $\mathrm{CO}_{2}$ and $\mathrm{CO}$ emissions profiles plotted from the LEMS software code during the rice and beans cooking tests respectively.

Table 4. Cooking test results of the hexagonal type charcoal stove.

\begin{tabular}{|c|c|c|c|}
\hline Basic Operation Performance of the stove & Units & Cooking test for $1.5 \mathrm{~kg}$ of rice & Cooking test for $2.0 \mathrm{~kg}$ of beans \\
\hline Cooking time of the food & $\min$ & 42 & 61 \\
\hline Burning rate of the stove & $\mathrm{g} / \mathrm{min}$ & 3 & 3 \\
\hline Thermal efficiency of the stove & $\%$ & 38 & 42 \\
\hline Specific fuel consumption & $\mathrm{g} /$ liter & 33 & 38 \\
\hline Firepower of the stove & watts & 1,569 & 1,644 \\
\hline Equivalent Dry Fuel Consumed & $\mathrm{g}$ & 94.0 & 199.1 \\
\hline
\end{tabular}

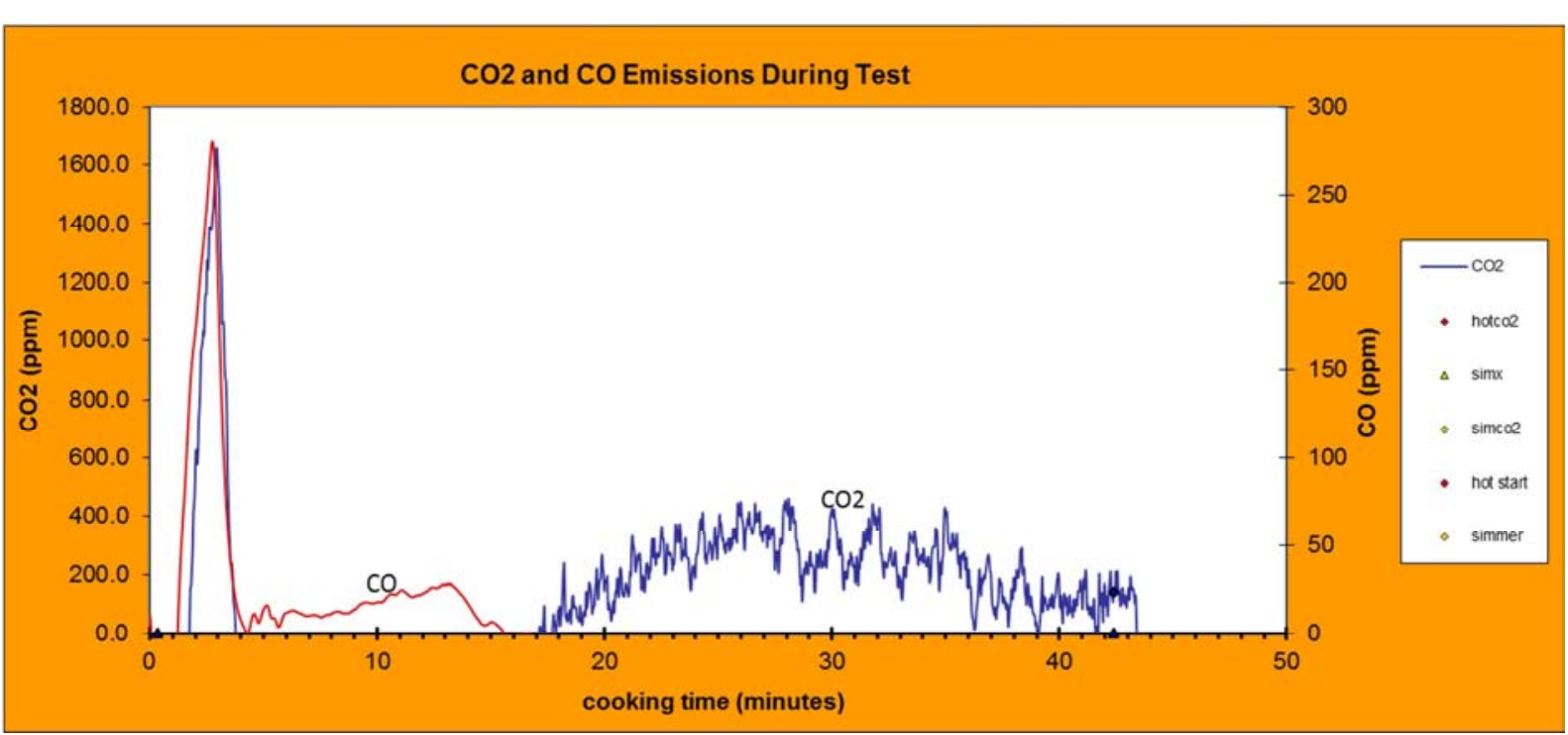

Figure 4. Carbon monoxide (CO), Carbon dioxide $\left(\mathrm{CO}_{2}\right)$ emissions profile during the rice cooking test. 


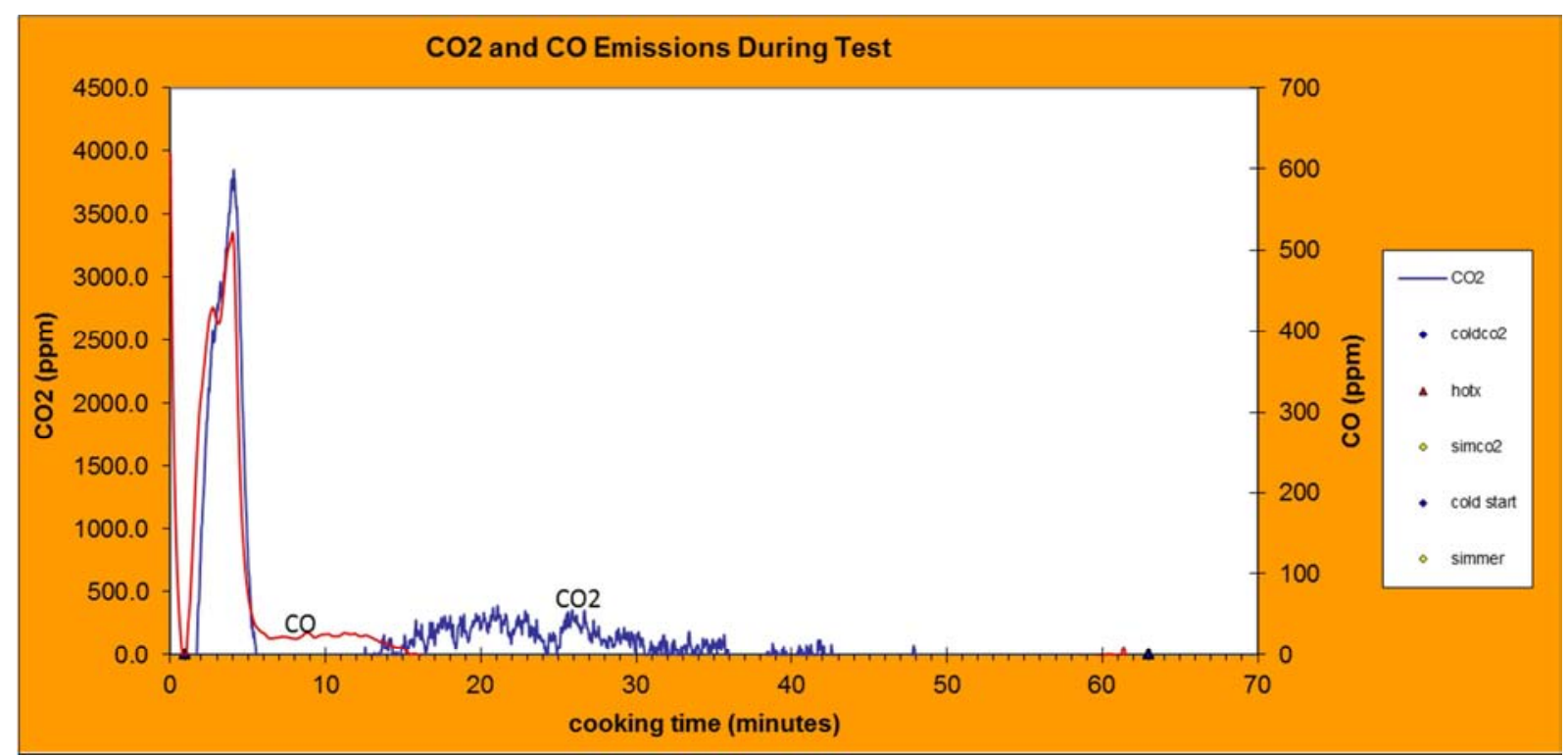

Figure 5. Carbon monoxide (CO), Carbon dioxide $\left(\mathrm{CO}_{2}\right)$ emissions profile during beans cooking test.

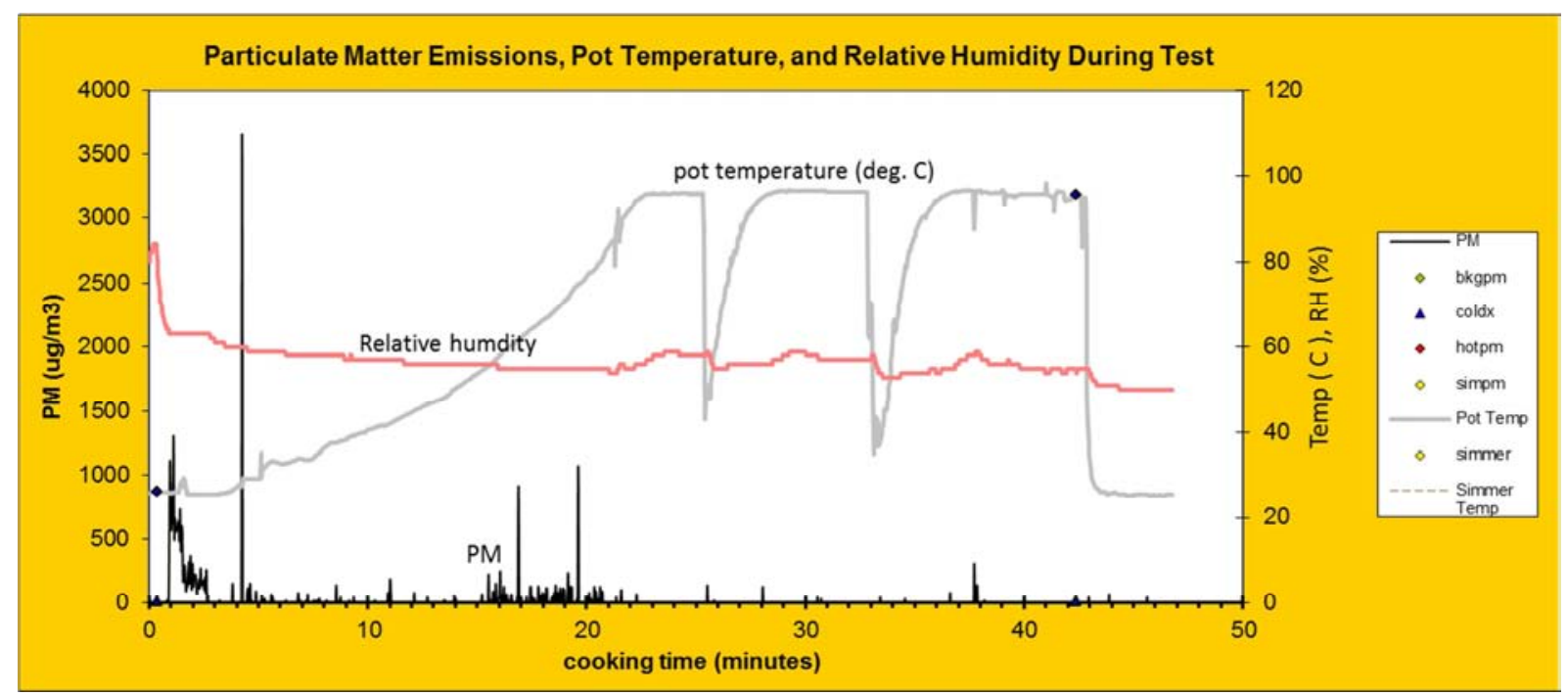

Figure 6. Particulate matter (PM) emissions, pot temperature, and relative humidity profile during the rice cooking test.

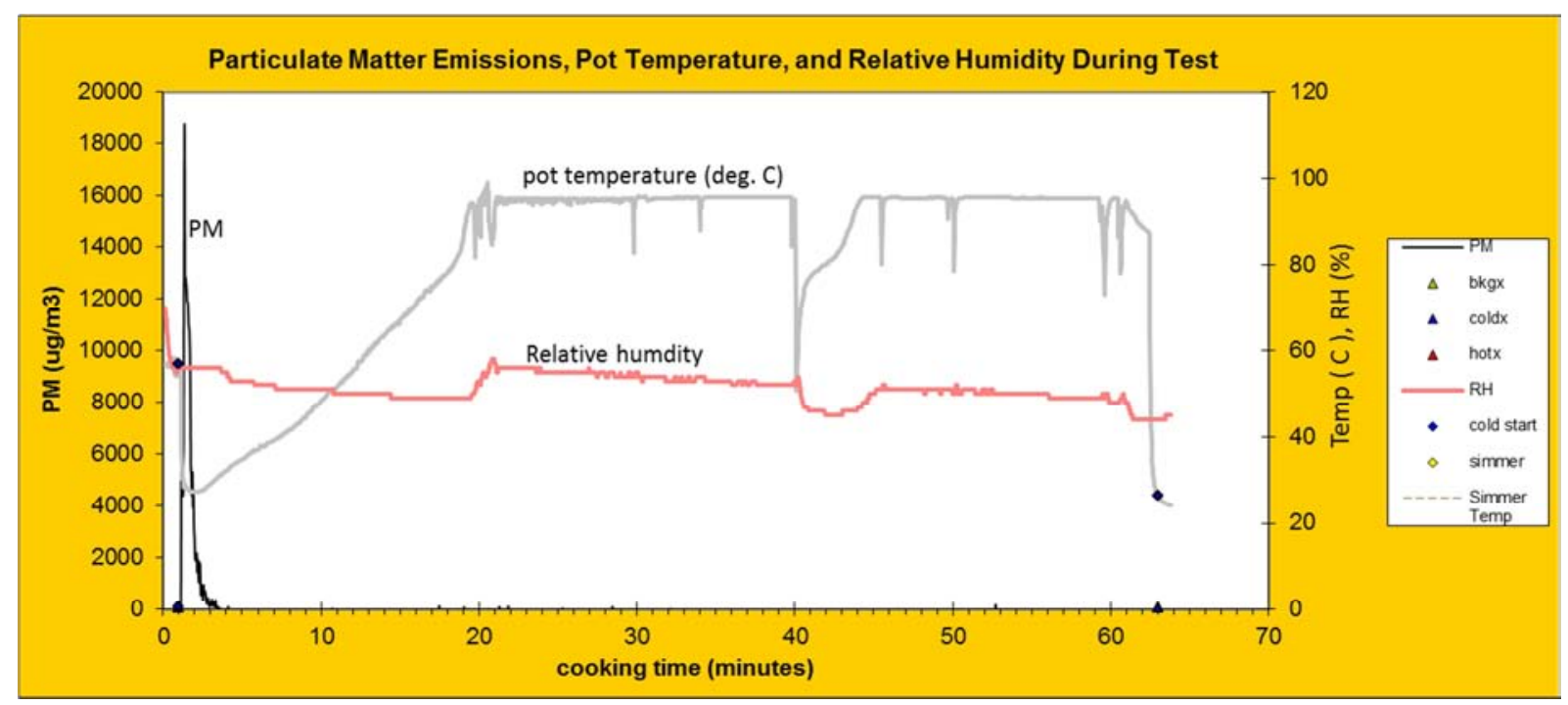

Figure 7. Particulate matter emissions, pot temperature, and relative humidity profile during the beans cooking test. 


\section{Biomass Clean Cookstoves Standard}

The standard for biomass clean cookstoves developed in 2015 by the National Mirror Committee on Clean Cooking solution and fuel standards under the leadership of SON was approved in 2017 by Governing Council of SON [16]. This is to address the quality and safety issues concerning the clean cookstoves sold in the Nigerian Market and to reduce health risk associated with inefficient cookstoves and other negative impacts such as deforestation and environmental pollutions.

\subsection{Thermal Efficiency and Emissions Performance Standard}

The SON stipulated that any biomass cook stove sold in the Nigerian Market must be fully tested in a Standard Laboratory by using Emissions Measuring System. The tested stoves must comply with the minimum standard described in Tables 5-7 for efficient performance and quality assurance $[16,17]$. Table 8 gives the thermal and emissions performance tires rating of biomass cookstoves as stipulated by IWA, VITA $[17,18]$.

Table 5. Thermal efficiency and fuel consumption.

\begin{tabular}{|c|c|c|c|}
\hline Type of stove & Chimney stove (Natural draft) & Chimneyless stove (Natural draft) & Forced draft stove (Fan stove) \\
\hline High power thermal efficiency (\%) & $\geq 20$ & $\geq 25$ & $\geq 35$ \\
\hline Specific fuel consumption $(\mathrm{MJ} / \mathrm{min} / \mathrm{L})^{*}$ & $\leq 0.045$ & $\leq 0.039$ & $\leq 0.028$ \\
\hline
\end{tabular}

*The high power values are mandatory values and low power values are preferred values only

Table 6. Total Emissions.

\begin{tabular}{lllll}
\hline Type of stove & & Chimney stove (Natural draft) & Chimneyless stove (Natural draft) & Forced draft stove (Fan stove) \\
\hline \multirow{2}{*}{ CO Emissions } & High power $\left(\mathrm{g} / \mathrm{MJ}_{\mathrm{d}}\right)$ & $\leq 16$ & $\leq 11$ \\
& Low power $(\mathrm{g} / \mathrm{min} / \mathrm{L})^{*}$ & $\leq 0.20$ & $\leq 0.13$ \\
$\mathrm{PM} 2.5$ & High power $\left.(\mathrm{g} / \mathrm{MJ})_{\mathrm{d}}\right)$ & $\leq 979$ & $\leq 386$ \\
Emissions & Low power $(\mathrm{g} / \mathrm{min} / \mathrm{L}) *$ & $\leq 8$ & $\leq 4$ & $\leq 168$ \\
\hline
\end{tabular}

*The high power values are mandatory values and low power values are preferred values only

Table 7. Indoor Emissions.

\begin{tabular}{llll}
\hline Types of stove & Chimney stove (Natural draft) & Chimneyless stove (Natural draft) & Forced draft stove (Fan stove) \\
\hline CO $(\mathrm{g} / \mathrm{min})$ & $\leq 0.42 * *$ & $\leq 0.62$ & $\leq 0.49$ \\
$\mathrm{PM} 2.5(\mathrm{mg} / \mathrm{min})$ & $\leq 2 * *$ & $\leq 17$ & $\leq 8$ \\
\hline
\end{tabular}

**The high power values are mandatory values and low power values are preferred values only

Table 8. Biomass cookstoves performance tiers.

\begin{tabular}{|c|c|c|c|c|c|c|c|c|c|c|c|}
\hline IWA VITA Tiers & Units & & Tier 0 & & Tier 1 & & Tier 2 & & Tier 3 & & Tier 4 \\
\hline High power thermal efficiency & $\%$ & $<$ & 0.15 & $\geq$ & $0.1 ` 5$ & $\geq$ & 0.25 & $\geq$ & 0.35 & $\geq$ & 0.45 \\
\hline Low power specific consumption & $\mathrm{MJ} / \mathrm{min} / \mathrm{L}$ & $>$ & 0.05 & $\leq$ & 0.05 & $\leq$ & 0.039 & $\leq$ & 0.028 & $\leq$ & 0.017 \\
\hline High power $\mathrm{CO}$ & $\mathrm{g} / \mathrm{MJd}$ & $>$ & 16 & $\leq$ & 16 & $\leq$ & 11 & $\leq$ & 9 & $\leq$ & 8 \\
\hline Low power $\mathrm{CO}$ & $\mathrm{g} / \mathrm{min} / \mathrm{L}$ & $>$ & 0.2 & $\leq$ & 0.2 & $\leq$ & 0.13 & $\leq$ & 0.1 & $\leq$ & 0.09 \\
\hline High power PM & $\mathrm{mg} / \mathrm{MJd}$ & $>$ & 979 & $\leq$ & 979 & $\leq$ & 386 & $\leq$ & 168 & $\leq$ & 41 \\
\hline Low power PM & $\mathrm{mg} / \mathrm{min} / \mathrm{L}$ & $>$ & 8 & $\leq$ & 8 & $\leq$ & 4 & $\leq$ & 2 & $\leq$ & 1 \\
\hline Indoor Emissions $\mathrm{CO}$ & $\mathrm{g} / \mathrm{min}$ & $>$ & 0.97 & $\leq$ & 0.97 & $\leq$ & 0.62 & $\leq$ & 0.49 & $\leq$ & 0.42 \\
\hline Safety & Index & $<$ & 45 & $\geq$ & 45 & $\geq$ & 75 & $\geq$ & 88 & $\geq$ & 95 \\
\hline
\end{tabular}

Source: Nigerian Industrial Standard, FDNIS 1000: 2017 [16, 18]

\subsection{Star Rating System for Biomass Cookstoves}

It is very essential that biomass cookstoves available in the Nigerian markets are rated to enable end-users make informed-decisions concerning the energy efficiency of the stove before purchasing. The star rating of biomass cookstoves are determined from the thermal efficiency tier value (TETV) of a stove expressed in Equation (9) [16]. A stove with thermal efficiency value of $29 \%$, for instance, the TETV could be determined as expressed in Equation (9). From Table 8 , a stove with thermal efficiency value of $29 \%$, falls within Tier 2, where $25 \leq \mathrm{TE} \quad 35$. Thus, the TETV is determined as follows:

$$
\text { TETV }=2+\frac{0.29-0.25}{0.35-0.25}=2.40
$$

In Equation (9), the overall star rating of a given stove is the average of the tier rating rounded up to the nearest integer. It is essential that the star rating of a stove should be printed boldly on the body of the stove as presented in the Figure 8 . A survey of the available cookstoves in the local markets in Nigeria indicates that the stoves do not display any star rating. However, any stove below star-2 rating is considered unsafe for use in Nigeria [16]. 


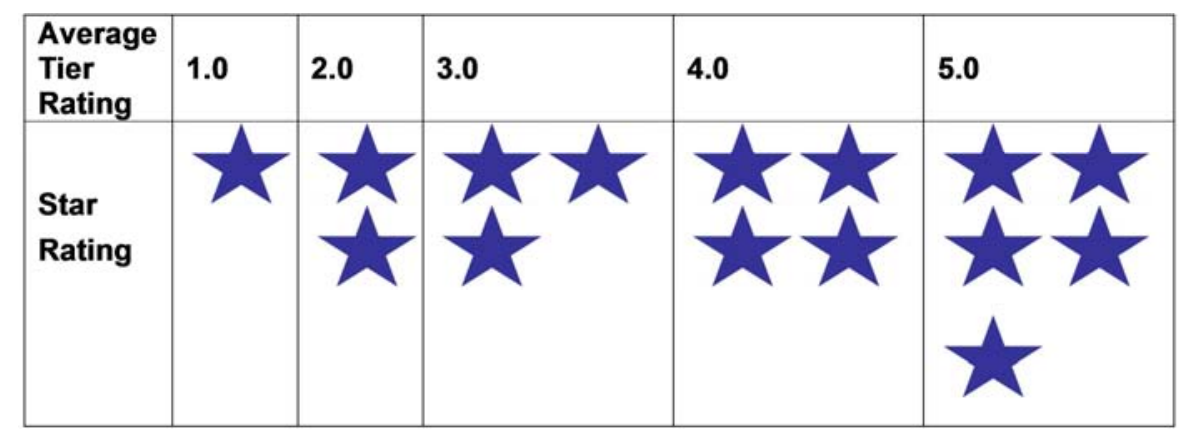

Source: Nigerian Industrial Standard, FDNIS: 2017 [16]

Figure 8. Star rating system for biomass cookstoves.

\subsection{Sampling Plan for Stove Testing and Verification}

Sampling technique for selecting the number of stoves samples for testing per batch is very critical in order to avoid erroneous conclusions. As presented in Table 9, samples of the stoves to be tested should be drawn from each lot for conducting verification of the product performance in conformity with the stipulated standard by SON [16].

Table 9. Sampling scale.

\begin{tabular}{lll}
\hline Number of clean cook stove in a Lot Sample Size & Number of stove to be selected & Samples to be tested \\
\hline Up to 50 & 5 & 2 \\
$>50-100$ & 10 & Minimum 20\% of number selected \\
$101-500$ & 15 & \\
$501-1000$ & 20 & \\
$>1000$ & 25 & \\
\hline
\end{tabular}

\subsection{Criteria for Acceptance and Quality Assurance}

At the end of the tests and analyses of data collected. As stipulated standard by SON, if over $90 \%$ of the tested samples drawn from the selected lot or batch passed, the lot or batch is said to have complied with the requirements of the Standard. If $>60 \%$ but $<90 \%$ of the samples passed, two additional samples can be taken from the selected lot or batch of the stoves for further test. If $<60 \%$ of the samples passed, the stoves in that lot or batch are said to have failed and the stoves are rejected. Efficient performance of the stoves cannot be guaranteed [16].

\section{Conclusion}

Inefficient biomass cookstoves waste fuel, create health problems and emissions $\left(\mathrm{CO}, \mathrm{CO}_{2}, \mathrm{PM}\right)$ into environment. Lack of standard laboratory in Nigeria has hampered quality assurance and performance evaluation standard of the few existing biomass cookstoves in the country. All the energy efficient cookstoves available in the local markets in Nigeria need to be fully tested and certified in line with the Standard before marketing them to end-users. Biomass Cook stoves Standard has been developed and approved SON in 2017 as a guide on stoves design, manufacture, quality and safety assurance in the interest of users, manufacturers and the nation in general. The standard is yet to be implemented. Presently, nearly all the biomass cookstoves available in the local markets in Nigeria have not been tested and the few tested at NSEL, NCERD, UNN were inconclusive. This could be due to non-enforcement of the standard and possibly lack of fund and incentives to enable the stove producers to undertake for full testing of the required sample test number of the stoves by Standard to attain full certifications.

\section{References}

[1] ICEED. 2007. Improved woodstoves Workshop and Exhibition. International Centre for Energy, Environment and Development http://www.iceednigeria.org/project

[2] M. A. Jeuland, and S. K. Pattanayak (2012). Benefits and Costs of Improved Cookstoves: Assessing the Implications of Variability in Health, Forest and Climate Impacts. PLoS One. 7 (2): e30338.

[3] WEO-2017 Special Report: Energy Access Outlook, International Energy Agency, 2017 (https://webstore.iea.org/weo-2017-special-report-energyaccess-outlook).

[4] H. Ali, Planting Trees: Is this Enough?: Beyond firewood: Exploring Alternative fuels and Energy technologies in humanitarian Settings. Conference, Delhi, India, 2008.

[5] M. B. Witt, An Improved Wood Cook Stove: Harnessing Fan Driven Forced Draft for Cleaner Combustion. Dept. of Mechanical Engineering, Trinity College, Hartford, CT. 2005.

[6] O. S. Adah, L. D. Shown, O. E. Yusuff, E. A. Envuladu, M. E. Banwat, A. Dhakin, M. P Chingle, S. Audu, and P. W. Bupwatda, Indoor Air Pollution in Rural Settings in Plateau State Nigeria. Jos Journal of Medicine, vol. 5, no. 1, pp. 30-33, 2010. 
[7] Unachukwu, G. O. Chinda G., Abada U. C. Nwoke O. Benchmarking of Energy Consumption of Common Domestic Cookstoves Available in Nigeria. Journal of Renewable and Alternative Energy Technologies, vol. 2, no. 1. pp. 32-39, 2016.

[8] Ayo, S. A., Design, Construction and Testing of an Improved Wood Stove. AU J. T. vol. 13, no 1, pp. 12-18, 2009.

[9] Instructions for Use of the Laboratory Emissions Monitoring System (LEMS), Aprovecho Research Center, Advanced Studies in Appropriate Technology Laboratory, Cottage Grove Oregon, USA, 2013.

[10] S. C. Bhattacharge, M. R. Siddique, M. Augustus, H. L. Pham and A. Mahandari, Study on Improved Institutional Biomass Stoves. Energy Programme, Asian Institute of Technology, Klong Luang, Pathumthiani, Thailand, 1984.

[11] R. Bailis, D. Ogle, N. MacCarty, K. R. Smith and R. Edwards, The Water Boiling Test (WBT) Version 3.0. Household Energy and Health Programme, Shell Foundation, pp. 2-7, 2007.
[12] B. B. Olalekan and O. Ayoola, Development of an Improved Coal Stove for Cooking in Developing Countries. AU. J. T., vol. 12, no. 3, pp. 82-187, 2009.

[13] WBT protocol version 4.2.3 for download at www.community.cleancookstoves.org/files

[14] VITA, Volunteers in Technical Assistance. Testing the efficiency of wood burning cookstoves: provisional international standards. Mt. Rainier, Mary-land, USA; 1982.

[15] S. A. Ayo, (2009). Design, Construction and Testing of an Improved Wood Stove. AU J. T. vol. 13, no. 1, pp. 12-18.

[16] Nigerian Industrial Standard, FDNIS 1000, 2017.

[17] ISO International Workshop Agreement: http://community.cleancookstoves.org/files/172

[18] Global Alliance for Clean Cookstove, Interim Reporting Requirements for IWA Tiers of Performance 2013 (http://community.cleancookstoves.org/discussions/viewtopic/ 22/80). 